\title{
Plasma digoxin concentrations in patients on admission to hospital
}

\author{
S. G. Carruthers, J. G. Kelly, and D. G. McDevitt
}

From the Department of Therapeutics and Pharmacology, The Queen's University of Belfast, and The Belfast City Hospital, Belfast, N. Ireland

Plasma digoxin concentrations on emergency admission to hospital were measured by radioimmunoassay in IOI patients who had been taking chronic maintenance digoxin therapy. The mean concentration was I.4I $\mathrm{ng} / \mathrm{ml}$. Fifty-eight patients had plasma levels outside the range 0.8 to $2.0 \mathrm{ng} / \mathrm{ml}$ : of these, 33 patients had levels below $0.8 \mathrm{ng} / \mathrm{ml}$ and may not have been given sufficient digoxin, while 25 patients had levels greater than $2.0 \mathrm{ng} / \mathrm{ml} ; 13$ patients with a mean plasma digoxin concentration of $2.76 \mathrm{ng} / \mathrm{ml}$ showed clinical evidence of digoxin toxicity. In the absence of clinical evidence of digoxin toxicity, it is impossible for the digoxin status of a patient who has been taking long-term treatment with the drug to be known without estimating his plasma digoxin concentration. The difficulties of prescribing digoxin to such patients after admission to hospital are discussed.

Since the recent introduction of a sensitive radioimmunoassay technique for estimating plasma digoxin concentrations (Smith, Butler, and Haber, 1969), considerable attention has been focused on the relation between plasma digoxin concentrations and digoxin toxicity in groups of patients taking digoxin in an attempt to define therapeutic and toxic ranges (Smith and Haber, 1970; Evered and Chapman, 1971; Fogelman et al., 1971; Beller et al., 197 ; Whiting, Sumner, and Goldberg, 1973). Most of these studies have been carried out in patients in hospital.

Despite this recent advance, there are still many problems associated with the use of digoxin in clinical practice. One of these is the judgement of the therapeutic dose when digoxin is given for its inotropic action, and, in consequence, the use of digoxin in the management of congestive cardiac failure in patients with normal sinus rhythm has been described as a 'clinical nemesis' (Knoebel, 1969). The problems of assessing digoxin dosage are accentuated in the patient admitted to hospital under emergency conditions who is already receiving chronic maintenance digoxin therapy. Scant attention has been given to the digoxin status of patients taking the drug as outpatients, and, therefore, in the absence of frank toxicity, little information is available to guide the physician in his

Received I February r974. prescribing during the first few days of a patient's hospital admission when the proper use of digoxin may be life-saving. This present study was undertaken to determine the plasma digoxin concentration of patients on chronic maintenance digoxin therapy at the time of emergency admission to hospital.

\section{Methods}

Patients admitted in emergency to a general medical ward in the Belfast City Hospital during the period from March 1972 to June 1973, who were receiving maintenance digoxin therapy before admission, were studied.

A blood sample for estimation of plasma digoxin concentration was drawn from each patient within one hour of his admission to hospital, unless he had recently received digoxin, in which case it was taken at least 8 hours after the previous dose. A careful history of digoxin therapy was taken, with particular reference to the dose level, the regularity with which treatment had been taken, the period elasping between the last dose and the blood sample, and the presence of subjective symptoms suggesting digoxin toxicity. In addition, a 12-lead electrocardiogram was obtained. Plasma electrolytes and urea were measured in all patients in the routine laboratory. Serum creatinine was measured in some of the patients.

Plasma digoxin levels were measured by the radioimmunoassay technique described by Smith et al. (1969), using the Wellcome $\beta$-Lanoxitest kit method, as modified by Ojala, Karjalainen, and Reissell (1972).

The occurrence of one or more of the following 
TABLE I Summary of data obtained on admission to hospital on maintenance digoxin therapy (mean values \pm $S D)$

\begin{tabular}{|c|c|c|c|c|c|c|c|}
\hline & $\begin{array}{l}\text { Plasma } \\
\text { digoxin } \\
\text { concentration } \\
(n g / m l)\end{array}$ & $\begin{array}{l}\text { Average } \\
\text { daily } \\
\text { digoxin } \\
\text { dose } \\
(m g)\end{array}$ & $\begin{array}{l}\text { Age } \\
(y r)\end{array}$ & $\begin{array}{l}\text { Blood } \\
\text { urea } \\
(\mathrm{mg} / \mathrm{loo} \mathrm{ml})\end{array}$ & $\begin{array}{l}\% \text { subjects } \\
\text { with blood } \\
\text { urea } \\
>40 \mathrm{mg} / 100 \mathrm{ml}\end{array}$ & $\begin{array}{l}\text { Serum } \\
\text { creatinine } \\
(\mathrm{mg} / \mathrm{loO} \mathrm{ml})\end{array}$ & $\begin{array}{l}\text { Plasma } \\
\text { potassium } \\
(m E q / l .)\end{array}$ \\
\hline $\begin{array}{r}\text { All subjects Ior } \\
\mathrm{M}: 37, \mathrm{~F}: 64\end{array}$ & $\begin{array}{r}I \cdot 4 I \\
\pm I \cdot 3 I\end{array}$ & $\begin{array}{r}0.29 \\
+0.12\end{array}$ & $\begin{array}{r}70.9 \\
+\quad 9.0\end{array}$ & $\begin{array}{r}63.5 \\
+\quad 7.0\end{array}$ & $66 \cdot 7$ & $\begin{aligned} & 1 \cdot 8^{\star} \\
+ & 2 \cdot 1\end{aligned}$ & $\begin{array}{r}4.17 \\
+0.70\end{array}$ \\
\hline $\begin{array}{l}\text { Toxic subjects } 13 \\
\text { (12.9\%) } \\
\text { M: } 6 \text { F: } 7\end{array}$ & $\begin{array}{r}2.76 \\
+0.69\end{array}$ & $\begin{array}{r}0.36 \\
\pm 0.18\end{array}$ & $\begin{array}{r}69.9 \\
+10 \cdot 0\end{array}$ & $\begin{array}{r}83.3 \\
\pm 53.7\end{array}$ & $67 \cdot 1$ & $\begin{array}{l}4.6 \dagger \\
\pm 7 \cdot 3\end{array}$ & $\begin{array}{r}4.32 \\
\pm 0.45\end{array}$ \\
\hline $\begin{array}{l}\text { Non-toxic subjects } 88 \\
(87 \cdot 1 \%) \\
\text { M: } 3 \text { I, F: } 57\end{array}$ & $\begin{array}{r}I \cdot 2 I \\
\pm I \cdot 22\end{array}$ & $\begin{array}{r}0.28 \\
\pm 0.11\end{array}$ & $\begin{array}{r}71 \cdot 0 \\
\pm 9 \cdot 4\end{array}$ & $\begin{array}{r}61 \cdot 0 \\
\pm 3 I \cdot 9\end{array}$ & $66 \cdot 3$ & $\begin{array}{l}I \cdot 4 I \ddagger \\
\pm 0.7\end{array}$ & $\begin{array}{r}4.16 \\
\pm 0.75\end{array}$ \\
\hline
\end{tabular}

*5I subjects only; †6 subjects; $¥ 45$ subjects.

criteria was used to support a diagnosis of digoxin intoxication.

I) Nausea and/or vomiting - without evident other cause and which resolved on withdrawal of digoxin.

2) The following arrhythmias which resolved on withholding the drug: a) paroxysmal supraventricular tachycardia with or without AV block; b) nodal arrhythmias; c) heart block of any degree; d) ventricular premature contractions; and e) atrial fibrillation with high grade atrioventricular block.

\section{Results}

Studies were made on ror subjects, of whom 37 were men and 64 were women. The results, expressed as the mean \pm standard deviation, are summarized in Table $\mathrm{I}$.

The mean plasma digoxin concentration in the total group was $\mathrm{I} \cdot 4 \mathrm{I} \pm \mathrm{I} \cdot 3 \mathrm{I} \mathrm{ng} / \mathrm{ml}$ on a mean daily dose of $0.29 \pm 0.12 \mathrm{mg}$. The daily maintenance dose in all subjects ranged from 0.0625 to $0.75 \mathrm{mg}$. The mean plasma digoxin concentrations on admission at the 3 main dose levels are shown in Table 2 and Fig. I, which also shows the range of concentrations at each dose level. There was a positive correlation between plasma digoxin concentration and total

TABLE 2 Plasma digoxin concentrations on admission in IOI subjects

\begin{tabular}{llll}
\hline $\begin{array}{l}\text { Total } \\
\text { daily dose } \\
(\mathrm{mg})\end{array}$ & $\begin{array}{l}\text { No. of } \\
\text { subjects }\end{array}$ & $\begin{array}{l}\text { Mean plasma } \\
\text { digoxin } \\
\text { concentrations } \\
(\mathrm{ng} / \mathrm{ml})\end{array}$ & $S D$ \\
\hline$<0.25$ & 12 & 0.84 & \\
0.25 & 70 & 1.28 & 0.97 \\
$\geqslant 0.5$ & 19 & 1.95 & 0.89 \\
\hline
\end{tabular}

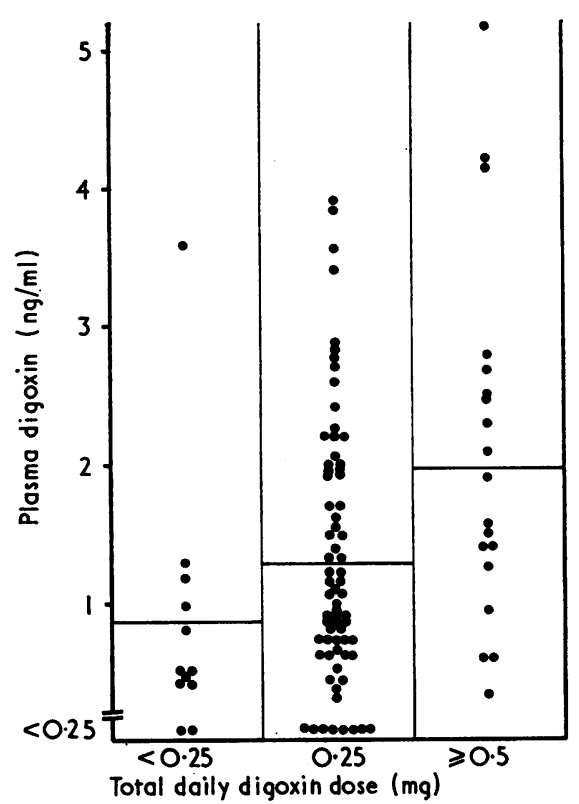

FIG. I Plasma digoxin concentrations on admission in relation to total daily digoxin dosage (mean values represented by horizontal bars).

daily digoxin dose $(r=0.35 ; P<0.001)$. The average age of all patients was $70.9 \pm 9 \cdot 0$ years and the mean blood urea was $63.5 \pm 7.0 \mathrm{mg} / 100 \mathrm{ml}$. A blood urea of greater than $40 \mathrm{mg} / 100 \mathrm{ml}$ was found on admission in 67 per cent of the total group, and there was a positive correlation between plasma digoxin concentration and blood urea $(r=0.23 ; P<0.05)$. Serum creatinine was measured in 51 patients, in 
TABLE 3 Plasma digoxin concentrations on admission compared with time elapsing from last dose

\begin{tabular}{llll}
\hline $\begin{array}{l}\text { Interval from } \\
\text { last digoxin } \\
\text { dose } \\
(\text { hr })\end{array}$ & $\begin{array}{l}\text { No. of } \\
\text { subjects }\end{array}$ & $\begin{array}{l}\text { Mean plasma } \\
\text { digoxin } \\
\text { concentrations } \\
(\text { ng/ml })\end{array}$ & $S D$ \\
\hline $8-24$ & 32 & $\mathrm{I} \cdot 60$ & $\mathrm{I} \cdot \mathrm{II}$ \\
24 & 32 & $\mathrm{I} \cdot 64$ & $\mathrm{I} \cdot 24$ \\
$24-48$ & 31 & $\mathrm{I} \cdot 02$ & 0.83 \\
48 & 6 & 0.29 & 0.49 \\
\hline
\end{tabular}

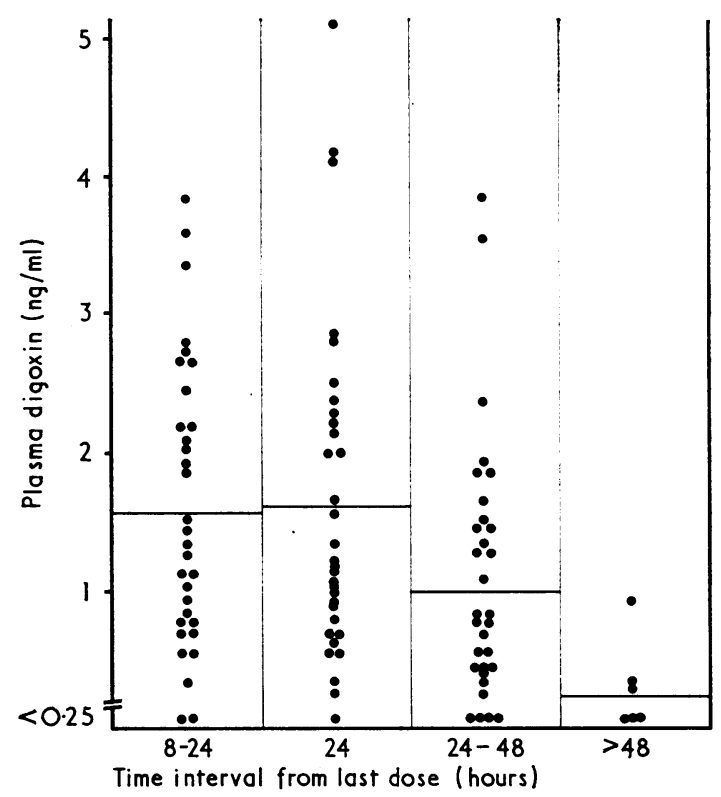

FIG. 2 Plasma digoxin concentrations on admission compared with time elapsing from last dose (mean values represented by horizontal bars).

whom the mean value was $\mathrm{I} \cdot 8 \pm 2 \cdot \mathrm{I} \mathrm{mg}$; a positive correlation was found between plasma digoxin level and serum creatinine $(r=0.43 ; P<0.01)$. The mean plasma potassium concentration was $4.17 \pm$ $0.70 \mathrm{mEq} / \mathrm{l}$.

The plasma digoxin concentrations on admission compared with the time elapsing from the last digoxin dose are shown in Table 3 and Fig. 2. The mean plasma digoxin concentration did not differ whether the last digoxin dose was taken within 24 hours before admission. Thirty-seven patients had not taken digoxin for more than 24 hours before admission despite being prescribed daily doses. They included some patients who admitted taking
TABLE 4 Nature of digoxin toxicity in 13 subjects (2 subjects had more than one manifestation of toxicity)

\begin{tabular}{ll}
\hline Digoxin toxicity & $\begin{array}{l}\text { No. of } \\
\text { subjects }\end{array}$ \\
\hline Nausea, anorexia, and vomiting & 7 \\
Paroxysmal atrial tachycardia with & \\
or without AV block & 3 \\
Premature ventricular contractions & 2 \\
First-degree heart block & 2 \\
Atrial fibrillation with high grade & IV block (VR <50/min) \\
\hline
\end{tabular}

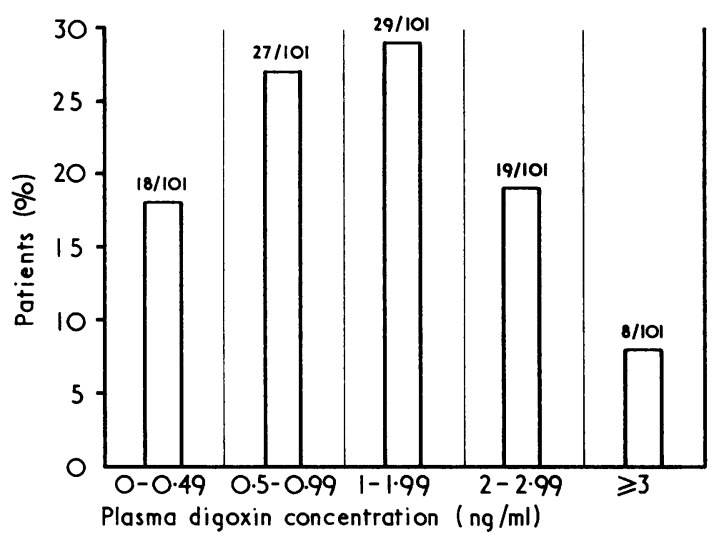

FIG. 3 Percentages of IOI patients on admission with different ranges of plasma digoxin concentrations.

their digoxin irregularly and others who had stopped taking their tablets when they began to feel ill. In this group the mean digoxin level was lower, and when more than 48 hours had elapsed, a mean level of $0.29 \pm 0.49 \mathrm{ng} / \mathrm{ml}$ was obtained. A negative correlation was found between plasma digoxin concentration and time elapsing from the last digoxin dose $(r=-0.33 ; P<0.001)$, though there was a considerable range at each time interval up to 48 hours. Levels of less than $0.25 \mathrm{ng} / \mathrm{ml}$ were found in 2 patients who said they had taken digoxin within the previous 24 hours.

Of the total group, 18 per cent had plasma digoxin concentrations of less than $0.5 \mathrm{ng} / \mathrm{ml}$ (Fig. 3). Plasma digoxin concentrations between 0.5 and $0.99 \mathrm{ng} / \mathrm{ml}$ were found in 27 per cent, and levels between $I \cdot O$ and $I .99 \mathrm{ng} / \mathrm{ml}$ in a further 29 per cent: 27 per cent had levels of $2.0 \mathrm{ng} / \mathrm{ml}$ or greater. About one-third of patients admitted to taking their digoxin irregularly, but no significant differences in 


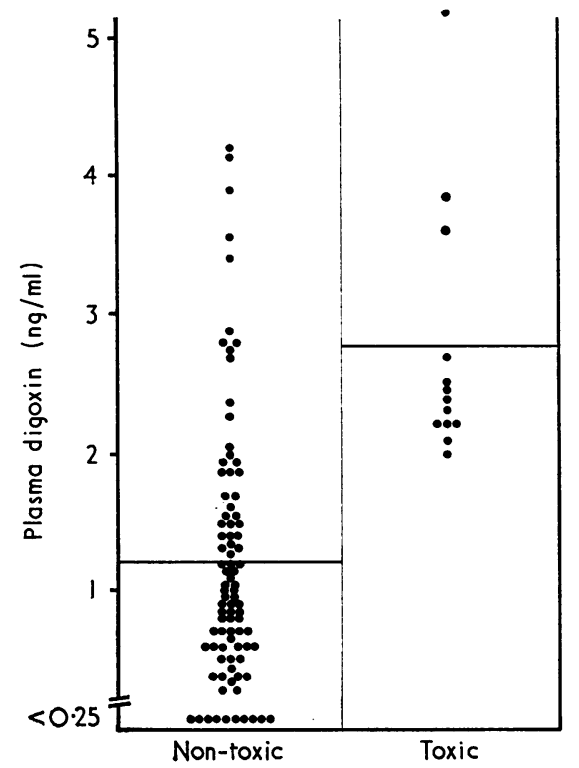

FIG. 4 Plasma digoxin concentrations in patients with and without digoxin toxicity (mean values represented by horizontal bars).

mean plasma digoxin concentrations occurred between patients who said they took their digoxin irregularly and those who did not.

Thirteen patients had evidence of digoxin toxicity on admission to hospital. The manifestations of this toxicity are shown in Table 4 , and the other characteristics of this group and of the patients who were non-toxic appear in Table $\mathrm{I}$. The mean plasma digoxin concentration was $2.76 \pm 0.69 \mathrm{ng} / \mathrm{ml}$ in the toxic group compared with $\mathrm{I} \cdot 2 \mathrm{I} \pm \mathrm{I} \cdot 22 \mathrm{ng} / \mathrm{ml}$ in the patients who were without signs of toxicity. The difference is not significant $(0 \cdot I>P>0.05)$. The range of plasma digoxin levels and the overlap between the toxic and non-toxic groups is shown in Fig. 4. The average daily digoxin dose and the mean blood urea concentration were higher in the toxic group than in the other patients but the average age of both groups was similar and approximately two-thirds of patients in both groups had blood urea concentrations greater than $40 \mathrm{mg} / 100 \mathrm{ml}$ on admission.

\section{Discussion}

Previous authors have concentrated not only on the observed plasma levels of patients with digoxin toxicity but also on defining the normal therapeutic range of plasma digoxin concentrations in clinical practice. There is general agreement that with a digoxin dosage of 0.25 to $0.50 \mathrm{mg}$ daily and in the presence of normal renal function, the mean plasma digoxin level in any group of non-toxic patients is likely to lie between $\mathrm{I}$ and $2 \mathrm{ng} / \mathrm{ml}$ (Smith et al., 1969; Smith and Haber, 1970; Chamberlain et al., 1970; Evered and Chapman, 1971; Whiting et al., 1973). Presumably because of this experience, Chamberlain et al. (1970) speak of 'a satisfactory therapeutic range of $\mathrm{I}-2 \mathrm{ng} / \mathrm{ml}$ ' and Whiting et al. (1973) of an 'observed "normal" therapeutic range of $0.8-2.0 \mathrm{ng} / \mathrm{ml}$ '. In most series, the mean plasma digoxin level associated with digoxin toxicity is above $3.0 \mathrm{ng} / \mathrm{ml}$ (Smith et al., 1969; Chamberlain et al., 1970; Evered and Chapman, 197I; Whiting et al., 1973), but the range of values is from $2 \cdot 0$ $\mathrm{ng} / \mathrm{ml}$ to $5.0 \mathrm{ng} / \mathrm{ml}$ or higher. Thus, it has been stated that a level of $2 \cdot 0 \mathrm{ng} / \mathrm{ml}$ represents a useful guideline and that caution should be exercised once this concentration is exceeded (Whiting et al., 1973).

If these standards are correct, the results of this present study are startling. On admission to hospital, 58 out of ror patients ( $57 \%$ ) had plasma digoxin levels outside the range 0.8 to $2.0 \mathrm{ng} / \mathrm{ml}$. Of these, $33(33 \%)$ were below $0.8 \mathrm{ng} / \mathrm{ml}$ and 25 $(25 \%)$ were above $2 \cdot 0 \mathrm{ng} / \mathrm{ml}$. Thus less than half of the patients could be considered to be getting optimum effect from their digoxin, without the potential or actual risks of toxicity. Thirteen patients showed clinical evidence of toxicity to digoxin; they all had a plasma digoxin concentration of $2.0 \mathrm{ng} / \mathrm{ml}$ or greater, with a mean of $2 \cdot 76 \pm 0.69 \mathrm{ng} / \mathrm{ml}$.

This present study and that of Beller et al. (197I) suggest that the level of toxicity in outpatients on regular digoxin therapy is comparable to that found in patients in hospital, though Baylis et al. (1972) found no evidence of toxicity in their 3 I patients. There is, in addition, a group of outpatients who have plasma digoxin concentrations greater than $2.0 \mathrm{ng} / \mathrm{ml}$ but who do not have clinical evidence of toxicity at the time of observation (Baylis et al., 1972; Weintraub, Au, and Lasagna, 1973). It appears to be important also to recognize a group of patients whose plasma digoxin concentrations are less than $0.8 \mathrm{ng} / \mathrm{ml}$ and who may not be receiving sufficient digoxin. These patients are found both in hospital (Evered, Chapman, and Hayter, 1970; Evered and Chapman, 1971 ; Chamberlain et al., 1970; Whiting et al., 1973) and outside it (Beller et al., 1971 ; Weintraub et al., 1973). This present study suggests that, in the latter situation, the number of patients with low plasma digoxin concentrations may be as large as one-third of the total group.

There may be several reasons for finding low plasma digoxin concentrations. Weintraub et al. (1973) considered that failure to take digoxin 
regularly was the principal cause in their series - up to 34 per cent of their patients admitted default and they considered the true proportion to be even higher. In this present study, though a similar proportion admitted to irregular digoxin taking, this did not appear to be responsible for the low plasma concentrations. Differences in the biological availability of digoxin from various tablet preparations, both between formulations from different manufacturers and also between different batches of tablets from the same firm, have been shown recently (Shaw, Howard, and Hamer, I972). Thus, seemingly adequate doses might produce serumdigoxin levels below the usual therapeutic range (Manninen, Melin, and Härtel, I97I ; Binnion and McDermott, 1972). Though the type of digoxin used by each patient was not recorded in this present study, this factor may well have been related to some of the low plasma digoxin concentrations obtained. Inadequate dosage, improper packaging or labelling, altered digitalis metabolism, malabsorption, and hyperthyroidism have also been implicated (Butler, 1972) but were not identified in any of our patients.

It is difficult to elucidate factors which might be valuable clinically in predicting digoxin status in patients. Daily digoxin dose, interval from last digoxin dose, blood urea level, and serum creatinine concentration were all found to correlate with plasma digoxin concentration, but none of these parameters was useful in predicting digoxin concentrations in particular patients. Formulae interrelating these factors (and including body weight) have been derived that undoubtedly improve the correlation of dosage with plasma digoxin concentration. However, in a recent study, in which this information was incorporated in a computer programme to assess the digoxin dosage necessary to achieve a serum digoxin concentration of $\mathrm{I} \mathrm{ng} / \mathrm{ml}$ in a patient, the computer could only assure that the resulting value would be between 0.0 and $2 . \mathrm{I} \mathrm{ng} / \mathrm{ml}$ - that is, somewhere between ineffective and potentially toxic concentrations (Peck et al., 1973). It was concluded that factors other than patient size and renal function were important. As already indicated, a history of drug defaulting was not necessarily associated with a low plasma digoxin concentration, but some patients with chronic heart disease are asked to take several different types of tablets and may become confused about their drug programme without realizing it.

The unreliability of drug histories is illustrated by two individual cases, not strictly part of this study. One elderly woman, who denied taking digoxin on admission, had a plasma sample analysed for digoxin concentration as part of a control group being com- piled at that time. The plasma digoxin concentration was $0.25 \mathrm{ng} / \mathrm{ml}$ and on further questioning, the patient later admitted that she had, in fact, been taking digoxin for some time. On a second occasion, a 40-year-old man was admitted with chronic obstructive airways disease and severe cor pulmonale. Despite other conventional treatment, he failed to improve, and it was, therefore, decided to give digoxin. Close questioning of both the patient and his wife, who was a nurse, brought persistent denial that he had ever taken digoxin previously. $\mathrm{He}$ was given digitalizing doses of digoxin orally over several days and initial and daily samples of blood were obtained for plasma digoxin estimation until his death 6 days after digoxin was started. The samples were analysed after his death and it was found that the control sample before digoxin was given had a plasma digoxin concentration of $\mathrm{I} \cdot 9 \mathrm{ng} / \mathrm{ml}$. The consecutive daily samples until his death showed plasma digoxin concentrations of $4.2,3.8,3.65,3.85,4.1$, and $4.73 \mathrm{ng} / \mathrm{ml}$. It seems likely, therefore, that he had taken digoxin before his admission, and it is possible that the digitalizing doses given in hospital may have contributed to his death.

A physician faced with a patient admitted to hospital under emergency conditions, with a history of taking maintenance digoxin therapy, has an almost equal chance of his having a plasma digoxin level below, above, or within the 'normal therapeutic range' of $0.8-2 \cdot 0 \mathrm{ng} / \mathrm{ml}$. He must decide whether such a patient requires more, less, or a continuation of digoxin at his previous maintenance level. For the patient with atrial fibrillation there may be some index in the ventricular rate to guide the physician about digoxin status, though Chamberlain et al. (1970) showed a poor correlation between plasma digoxin concentration and resting heart rate during atrial fibrillation, and some of their patients with ventricular rates between 60 and 85 beats a minute had concentrations below $0.8 \mathrm{ng} / \mathrm{ml}$. However, in the patient in congestive heart failure with normal sinus rhythm where digoxin is being given for its inotropic action, clinical judgement of adequate digitalization is even more difficult, if not impossible, as there is no simple clinical way of assessing cardiac contractility.

Advice on how to treat patients who have already received digoxin is difficult to obtain. Laurence (1973) advises that a full digitalizing dose should not be given if digoxin has been taken in the previous 5 days. Friedberg (1966) comments that, 'if digitalis has been given in the preceding 2 weeks and further digitalisation appears necessary, the amount remaining may possibly be calculated and subtracted from the dose that would have been given if the 
patient were digitalis-free. But if there is any doubt it is safer to digitalise slowly ... while observing the patient carefully for therapeutic or toxic effects.' He suggests the use of digoxin, $0.5 \mathrm{mg}$, every 8 hours in these circumstances. In clinical practice, some physicians continue digoxin at the maintenance dose being taken on admission unless the patient is obviously toxic. The relevance of any of these potential approaches is difficult to see in the light of the plasma digoxin concentrations found in patients on admission to hospital in the present study.

It appears, therefore, that in the present circumstances, in the absence of clinical evidence of digoxin toxicity, it is impossible to predict accurately the digoxin status or the necessary digoxin dose required in any patient taking chronic maintenance digoxin therapy on admission to hospital without knowledge of the plasma digoxin concentration. As many as two-thirds of patients may have concentrations outside the therapeutic range, and it is probable that until the factors governing plasma digoxin concentration have been more clearly elucidated, subsequent serial measurements after dose adjustment may be the only method of ascertaining that normal plasma digoxin concentrations have been attained.

We would like to thank Miss G. McClean for technical assistance.

\section{References}

Baylis, E. M., Hall, M. S., Lewis, G., and Marks, V. (1972). Effects of renal function on plasma digoxin levels in elderly ambulant patients in domiciliary practice. British Medical fournal, $\mathbf{r}, 338$.

Beller, G. A., Smith, T. W., Abelmann, W. H., Haber, E., and Hood, W. B. (1971). Digitalis intoxication - A prospective clinical study with serum level correlations. New England fournal of Medicine, 284, 989.

Binnion, P. F., and McDermott, M. (1972). Bioavailability of digoxin. Lancet, 2, 592.

Butler, V. P. (1972). Assays of digitalis in the blood. Progress in Cardiovascular Diseases, 14, 571.
Chamberlain, D. A., White, R. J., Howard, M. R., and Smith, T. W. (1970). Plasma digoxin concentrations in patients with atrial fibrillation. British Medical fournal, 3, 429.

Evered, D. C., and Chapman, C. (197I). Plasma digoxin concentrations and digoxin toxicity in hospital patients. British Heart fournal, 33, 540.

Evered, D. C., Chapman, C., and Hayter, C. J. (1970). Measurement of plasma digoxin concentration by radioimmunoassay. British Medical fournal, 3, 427.

Fogelman, A. M., La Mont, J. T., Finkelstein, S., Rado, E., and Pearce, M. L. (I97I). Fallibility of plasma-digoxin in differentiating toxic from non-toxic patients. Lancet, 2, 727.

Friedberg, C. K. (1966). The treatment of congestive heart failure; the administration of digitalis. In Diseases of the Heart, 3rd ed., p. 371. W. B. Saunders, Philadelphia and London.

Knoebel, S. K. (1969). General concepts underlying the clinical use of digitalis. In Digitalis, p. I2I. Ed. by C. Fisch and B. Surawicz. Grune and Stratton, New York.

Laurence, D. R. (1973). Digitalis and anti-arrhythmic drugs. In Clinical Pharmacology, 4th ed., p. 198. Churchill Livingstone, Edinburgh and London.

Manninen, V., Melin, J., and Härtel, G. (1971). Serumdigoxin concentrations during treatment with different preparations. Lancet, 2, 934.

Ojala, K., Karjalainen, J., and Reissell, P. (1972). Radioimmunoassay of digoxin. Lancet, $1,150$.

Peck, C. C., Sheiner, L. B., Martin, C. M., Combs, D. T., and Melmon, K. L. (1973). Computer-assisted digoxin therapy. New England fournal of Medicine, 289, 44I.

Shaw, T. R. D., Howard, M. R., and Hamer, J. (1972). Variation in the biological availability of digoxin. Lancet, 2, 303.

Smith, T. W., Butler, V. P., and Haber, E. (1969). Determination of therapeutic and toxic serum digoxin concentrations by radioimmunoassay. New England fournal of Medicine, 281, I212.

Smith, T. W., and Haber, E. (1970). Digoxin intoxication: the relationship of clinical presentation to serum digoxin concentration. Fournal of Clinical Investigation, 49, 2377.

Weintraub, M., Au, W. Y. W., and Lasagna, L. (I973). Compliance as a determinant of serum digoxin concentration. Fournal of the American Medical Association, 224, 48I.

Whiting, B., Sumner, D. J., and Goldberg, A. (1973). An assessment of digoxin radioimmunoassay. Scottish Medical fournal, 18, 69.

Requests for reprints to Dr. D. G. McDevitt, Department of Therapeutics and Pharmacology, Institute of Clinical Science, Grosvenor Road, Belfast, BTr2 6BJ, Northern Ireland. 